PSYCHOLOGIA ROZWOJOWA, $2018 *$ tom 23 , nr 1 , s. $69-88$

doi:10.4467/20843879PR.18.004.8599

www.ejournals.eu/Psychologia-Rozwojowa

ANNA ANTONINA NOGAJ

Instytut Psychologii, Uniwersytet Kazimierza Wielkiego w Bydgoszczy, Bydgoszcz

Institute of Psychology, Kazimierz Wielki University, Bydgoszcz

e-mail:nogaj@ukw.edu.pl

\title{
Temperament i kompetencje społeczne uczniów szkół artystycznych w okresie późnej adolescencji
}

\section{Temperament and Social Competences of Students of Art and Music Schools at the Age of Late Adolescence}

\begin{abstract}
The article focuses on the specificity of psychosocial functioning of the music and art schools students. The research presented revealed the differences between the musical and artistic talented adolescents in terms of the temperament traits and social competences. Comparative group consisted of students of general schools. 354 students took part in the study, of which $45 \%$ were music schools students, $28 \%$ were art schools students, and $27 \%$ were the students of general schools. The assumption was made that the profile of education represented by particular groups of art and music schools students is tantamount to having an elevated level of musical or artistic skills. The surveyed students of general schools declared lack of both interest in art and artistic abilities. The results of the research revealed that the students of art and music schools exhibit significantly higher level of endurance (conceived as an attribute of temperament, measured by the Temperament Questionnaire - Formal Characteristics of Behavior by Bogdan Zawadzki and Jan Strelau) than the students of general schools. On the other hand, in terms of social competences (measured by Anna Matczak's Social Competence Questionnaire) students of art schools exhibit a significantly lower level of ability in the field of social exposure than the students of music schools and general schools.
\end{abstract}

Keywords: temperament, social competences, music, art, students.

Słowa kluczowe: temperament, kompetencje społeczne, muzyka, plastyka, uczniowie.

\section{WPROWADZENIE}

Ponad 200-letnia tradycja kształcenia artystycznego w Polsce (Jankowski, 2002; Kowalski, 2005) pozwoliła na wnikliwe obserwowanie funkcjonowania młodych utalentowanych artystycznie osób rozwijających swoje zdolności muzyczne i plastyczne w profesjonalnym systemie szkolnictwa artystycznego. W powszechnej opinii uczniowie szkół muzycznych i plastycznych wydają się odmienni w porównaniu ze swoimi rówieśnikami, którzy nie rozwijają twórczych zdolności w ramach specjalistycznego kształcenia artystycznego. Obserwację tę potwierdzają wyniki badań realizowanych wśród młodych adeptów sztuki muzycznej lub plastycznej. Wybrane wyniki wskazuja, że młodzi muzycy, w porównaniu $\mathrm{z}$ rówieśnikami niekształcącymi się w szkołach muzycznych, charakteryzują się m.in.: podwyższonym poziomem inteligencji ogólnej (Sękowski, 1989), podwyższonym poziomem neurotyczności (Kemp, 1996; Manturzewska, 2014), wysokim poziomem perfekcjonizmu korelującego dodatnio z motywacją wewnętrzną, podejmowanym wysiłkiem i osiągnięciami 
(Stoeber, Eismann, 2007), podwyższoną potrzebą poczucia podziwu oraz wyznawaniem wartości humanistycznych i tradycjonalistycznych (Poraj-Weder, Sekścińska, 2012), a także deklarowaniem potrzeby otrzymywania wysokiego poziomu wsparcia od osób z najbliższego otoczenia (Nogaj, Ossowski, 2015). Z kolei uczniów szkół plastycznych bardzo często wyróżnia podwyższony poziom wrażliwości, megalomania i egocentryzm, przy obniżonej samoocenie. Charakteryzuje ich także silna koncentracja na zadaniu twórczym przy jednoczesnym roztargnieniu i niezaradności życiowej, operatywność twórcza przy naiwności w ocenach społecznych oraz silne wahania nastroju od euforii do pesymizmu i melancholii (por. Popek, 2010). Często zdolnościom plastycznym towarzyszy wysoka inteligencja, wyobraźnia i doskonała pamięć wzrokowa (Kerschensteiner, 1905, za: Chruszczewski, 2009; Limont, 1998). Wybrane badania studentów studiów plastycznych pokazują, że wyróżnia ich także ekstrawersja oraz częściej występująca tendencja do kierowania się intuicją niż studentów kierunków ścisłych (Per, Beyoglu, 2011). Ponadto obserwacje i badania biograficzne ujawniają duże zróżnicowanie stylów pracy artystów muzyków i artystów plastyków. Tych pierwszych wyróżnia codzienny, systematyczny trening muzyczny, przypominający reżimem charakter treningów sportowych. Ci drudzy przejawiają bardziej zróżnicowane strategie tworzenia, wymagające także systematyczności i zaangażowania, ale często będące rezultatem głębokiego natchnienia i wynikające z potrzeby chwili.

W tym miejscu warto podkreślić, iż w światowej literaturze przedmiotu znajdujemy liczne badania dotyczące funkcjonowania osób uzdolnionych artystycznie lub w zakresie nauk humanistycznych czy ścisłych (por. Csikszentmihalyi, 2005; Ericsson, 1996; Freeman, 2010). Badania te koncentrują się głównie na wyjaśnieniu tego, co stanowi potencjał osób uzdolnionych, jaka jest struktura ich zdolności oraz jakie właściwości funkcjonowania odróżniają ich od rówieśników nieprzejawiających szczególnych specjalistycznych uzdolnień (Winner, 1996). Ważne wydaje się zagadnienie, $w$ jakim stopniu osoby uzdolnione w różnych kierunkach są odmienne w zakresie wybranych wymiarów psychospołecznego funkcjonowania. W Polsce unikatowe badania w tym zakresie zrealizował Michał H. Chruszczewski (2009), który porównywał profile uzdolnień uczniów szkół muzycznych i plastycznych w wymiarze intelektualnym i osobowościowym. Wyniki jego badań pokazały, że uczniowie szkół plastycznych wyróżniają się spośród uczniów szkół muzycznych istotnie wyższym poziomem zdolności wzrokowo-przestrzennych, ale nie poziomem inteligencji skrystalizowanej czy poziomem otwartości na doświadczenia. Z kolei uczniowie szkół muzycznych wyróżniają się wyższym poziomem ugodowości, ale nie przejawiają w stosunku do uczniów szkół plastycznych istotnie wyższego poziomu sumienności. Kolejne badania (Nogaj, Owczarz, 2015) porównujące uczniów różnych typów szkół artystycznych ujawniły, że uczniów uzdolnionych muzycznie cechuje istotnie wyższy poziom wewnętrznego umiejscowienia poczucia kontroli niż uczniów uzdolnionych plastycznie.

Kontynuując nurt badań nad psychologicznymi sylwetkami osób uzdolnionych artystycznie (por. Amos, 1978; Kemp, 1996; Kobori i in., 2011; Manturzewska, 2014; Popek, 1987), w niniejszym artykule skoncentrowano się na pomiarze cech temperamentu i kompetencji społecznych uczniów szkół muzycznych i plastycznych w okresie późnej adolescencji. Założono, że na okres dorastania przypada osiągnięcie i stabilizowanie się dojrzałej tożsamości artystycznej (por. Bardziejewska, 2005; Nogaj, 2014). Wówczas czynniki osobiste (wśród nich zdolności poznawcze, temperament i style uczenia się), czynniki społeczno-kulturowe (wśród nich wpływ otoczenia i zdolności interpersonalne) oraz czynniki artystyczne (takie jak np. poziom zdolności kierunkowych czy umiejętność publicznej prezentacji) są rozwinięte na wysokim poziomie i współwystępują ze sobą, tworząc swoistą charakterystykę młodego artysty (por. North, Hargreaves, 2008).

Spośród całego spektrum cech psychospołecznych wybrano temperament $\mathrm{i}$ kompetencje społeczne, ponieważ w sposób zasadniczy wpływają one na powodzenie życiowe człowieka w poszczególnych okresach rozwoju. 
Temperament, choć ma swoją podstawę we wrodzonych mechanizmach fizjologicznych i biochemicznych oraz odnosi się do pierwotnie/ biologicznie zdeterminowanych cech osobowości (Zawadzki, Strelau, 1997; Strelau, 2006), ulega powolnym zmianom wynikającym z wpływów środowiskowych (Strelau, 2001). Z kolei kompetencje społeczne powstają w wyniku treningu społecznego, którego intensywność zależy od uwarunkowań osobowościowo-temperamentalnych, a efektywność od inteligencji, w tym od inteligencji emocjonalnej (Matczak, 2001; Argyle, 1998). Temperament uwarunkowany biologicznie niejako przenika kompetencje społeczne, które determinują efektywność funkcjonowania w sytuacjach społecznych. Wśród składników kompetencji społecznych wymienia się zarówno inteligencję społeczną (zdolność do rozumienia innych ludzi, zdarzeń i procesów społecznych), jak i wybrane cechy temperamentu (refleksyjność i opanowanie) oraz charakteru (aktywność społeczna i uprzejmość) (Greenspan, 1981, za: Matczak, 2001). Powyższe wymiary funkcjonowania mają niebagatelne znaczenie w rozwoju młodych adeptów sztuki, od których wymaga się umiejętności radzenia sobie w bardzo zróżnicowanych sytuacjach społecznych, niejednokrotnie o stresogennym charakterze.

\section{TEMPERAMENT I KOMPETENCJE SPOLECZNE W ROZWOJU ARTYSTYCZNYM}

Reprezentanci nurtu badań z zakresu psychologii muzyki i psychologii twórczości są zgodni w twierdzeniu, że powodzenie i osiągnięcia artystyczne w edukacji muzycznej lub plastycznej nie zależą tylko i wyłącznie od wysokiego poziomu zdolności kierunkowych. Zależą także od szerokiego spektrum właściwości indywidualnych, czyli od określonej konstelacji cech temperamentalnych, od kompetencji intelektualnych i społecznych, od wrażliwości emocjonalnej, od poziomu i kierunku motywacji, a także od umiejętności optymalnego radzenia sobie ze stresem w kontekście ekspozycji publicznej (por. Buttsworth, Smith,
1995; Gaunt, Hallam, 2009; Kemp, 2009; Manturzewska, 2014; Popek, 2010; Sloboda, Howe, 1999; Stoeber, Eismann, 2007; Whitesel, 1984). Uczeń kończący liceum muzyczne lub plastyczne prezentuje nie tylko wysoki poziom rozwoju zdolności artystycznych. Jest on jednocześnie osobą przejawiającą ukształtowane właściwości funkcjonowania i zachowania, które silnie różnią go od osób nieposiadających zdolności artystycznych.

Poznanie cech temperamentu i kompetencji społecznych młodych adeptów sztuki muzycznej i plastycznej wydaje się istotne, ponieważ są to wymiary funkcjonowania, które - rozwijając się optymalnie w ciagu życia - zapewniają adaptację do oczekiwań otoczenia społecznego. Badacze temperamentu zauważaja jednak niepokojące zjawisko zacierania się granic między osobowością a temperamentem (por. Strelau, 2014), w świetle wybranych definicji bowiem osobowość mieści w sobie cechy temperamentu, a nawet kompetencje społeczne (Caspi, Silva, 1995; Rothbart, 2011). Analizując wyniki badań z psychologii muzyki i twórczości, można zauważyć, że wśród cech osobowego funkcjonowania artystów wskazywane są zarówno ich właściwości wynikające z biologicznego wyposażenia, jak i będące rezultatem czynników środowiskowych. Anthony Kemp (1996), pionier szeroko zakrojonych badań nad temperamentem muzyków, stwierdził, że tę grupę artystów wyróżnia podwyższony poziom neurotyczności, niezależności, wrażliwości i niepokoju. Często utożsamiają oni swoją samoocenę z tym, jak radzą sobie z występami publicznymi (Dews, Williams, 1989). Z uwagi na silne poczucie muzycznej tożsamości niezwykle trudne dla muzyków jest rozpoznanie różnic między samooceną a poczuciem własnej skuteczności (Smith, Maragos, Van Dyke, 2000). Zauważalne są także różnice w cechach osobowości muzyków reprezentujących poszczególne specjalności instrumentalne. Muzycy grający na instrumentach smyczkowych są zdecydowanie bardziej introwertywni, radykalni w poglądach, ale i bardziej twórczy niż muzycy grający na instrumentach dętych. Z kolei tych ostatnich wyróżnia podwyższony poziom ekstrawersji, ale niższy poziom samodyscypliny i inteligencji 
(por. Langendörfer, 2008; Davies, 1978; Wilson, 1984, za: Gaunt, Hallam, 2009). Nie odnotowano istotnych różnic $\mathrm{w}$ profilach osobowości muzyków wykonawców i muzyków nauczycieli (Wubbenhorst, 1994). Wyniki nielicznych badań realizowanych z udziałem uczniów i absolwentów szkół plastycznych wskazują natomiast, że młodzi artyści plastycy są bardziej serdeczni, wrażliwi emocjonalnie, posiadają wyższy poziom wyobraźni i otwartości na zmiany, a także odczuwają wyższy poziom perfekcjonizmu i ogólnego napięcia (Furnham, Crump, 2013) przy jednocześnie wyższym poziomie inteligencji emocjonalnej (Lupu, 2013) niż uczniowie.

$\mathrm{Z}$ kolei kompetencje społeczne adolescentów uzdolnionych artystycznie wykraczają daleko poza typowe dla tego okresu zmiany rozwoju społecznego związanego z budowaniem nowych relacji z rodziną i rówieśnikami oraz z szeroko rozumianym społeczeństwem (por. Oleszkowicz, Senejko, 2011). Młody adept sztuki muzycznej i plastycznej, pracując od najmłodszych lat nad rozwojem własnych zdolności artystycznych, regularnie uczestniczy $\mathrm{w}$ indywidualnej relacji z nauczycielem artystą. W okresie późnej adolescencji relacja mistrzuczeń nabiera charakteru dojrzałej, partnerskiej relacji, z której uczeń czerpie nie tylko fachową wiedzę, ale przede wszystkim inspirację do dalszego wszechstronnego kształcenia i poznawania świata artystycznego, adaptuje się do środowiska zawodowego i rozwija umiejętności artystyczno-wykonawcze oraz społeczne (por. Jaślar-Walicka, 1999; Manturzewska, 1990; Welch, Ockelford, 2009). Dodatkowym elementem rozwoju kompetencji społecznych związanych z podejmowaniem działalności artystycznej są wszelkie kontakty młodego artysty z odbiorcami jego dzieł. Szczególnie od uczniów szkół muzycznych wymaga się umiejętności generowania, a także odczytywania ruchów mimicznych i ruchów ciała związanych z muzycznym wykonawstwem (por. Davidson, 2007). Ekspresja artystyczna podczas prezentowania swojego dzieła służy wyrażaniu ładunku emocjonalnego przez artystę (Juslin, 2007). W tym kontekście kompetencje społeczne obejmują szeroki wachlarz zachowań, pozwalających uczniowi szkoły artystycznej na realizowanie zadań wpisanych w edukację artystyczną.

Literatura z zakresu psychologii muzyki i psychologii sztuki nie zawiera jednak informacji na temat występowania zależności między temperamentem a kompetencjami społecznymi artystów. Tym samym nie ma danych wyjaśniających, czy zdolności muzyczne lub plastyczne różnicują młodych artystów pod względem temperamentu i kompetencji społecznych. Tego rodzaju zależność badano przede wszystkim $\mathrm{u}$ dzieci najmłodszych, nie uwzględniając kontekstu zdolności artystycznych. Wyniki badań z zakresu psychologii rozwojowej ujawniły, że u niemowląt płci żeńskiej wstępuje korelacja między prawidłowymi kompetencjami społecznymi (interpersonalnymi), ujawnianymi w relacji z opiekunami, a takimi cechami temperamentu, jak: zdolność do zbliżania się i wycofywania, zdolności adaptacyjne oraz wyrażanie jakości nastroju przez optymalną proporcję emocji pozytywnych do negatywnych (Carson, Wagner, Schultz, 2001). Podkreśla się także, iż niemowlęta o prawidłowym poziomie koncentracji uwagi posiadają wyższy poziom kompetencji społecznych w okresie przedszkolnym (Vaughan Van Hecke i in., 2007). W rozwoju kompetencji społecznych szczególną rolę odgrywa jakość relacji dziecka z opiekunem, a przede wszystkim zachowania dorosłych, dzięki którym dziecko nabywa sprawności w podejmowaniu prawidłowych interakcji społecznych w późniejszym wieku (Rispoli i in., 2013). W okresie adolescencji niski poziom kompetencji społecznych oraz dominujący poziom neurotyczności w zakresie cech temperamentu determinują poziom odczuwanego lęku społecznego i trudności w realizacji zadań życiowych (Miers i in., 2013).

Warto zauważyć, że kształcenie artystyczne nie jest wolne od doświadczania przez uczniów zwiększonej liczby wymagań (Nogaj, Owczarz, 2015). Do najbardziej znaczących wymagań kształcenia artystycznego zaliczyć należy: (1) egzaminy, koncerty, audycje, przesłuchania konkursowe, w których obligatoryjnie uczestniczą uczniowie szkół muzycznych oraz (2) przeglądy, korekty, plenery i konkursy, w których uczestniczą uczniowie szkół plastycznych. 
Warunkiem sine qua non poradzenia sobie z tymi wyzwaniami jest posiadanie przez uczniów zdolności muzycznych lub plastycznych na wysokim poziomie. Jednak o efektywności ich funkcjonowania w warunkach zwiększonych wymagań w zakresie codziennej pracy, regularnego ćwiczenia i w obszarze ekspozycji publicznej decydują w niemałym zakresie ich indywidualne właściwości psychospołeczne. Wychodząc z założenia, że uczniowie kształcący się w określonym typie szkoły artystycznej mają co najmniej podwyższony poziom zdolności muzycznych lub plastycznych oraz że stawiane są przed nimi zróżnicowane, ale jednocześnie wysokie wymagania, podjęto próbę poznania, czy występują między nimi także różnice dotyczące cech temperamentu i kompetencji społecznych. Do badań wprowadzono grupę porównawczą reprezentowaną przez uczniów szkół ogólnokształcących, którzy zadeklarowali, że nigdy nie uczestniczyli oraz aktualnie nie uczestniczą w żadnych formach zajęć, które rozwijałyby ich zdolności muzyczne lub plastyczne. Wprowadzenie grupy kontrolnej miało na celu wyjaśnienie, czy różnice, jakie mogą występować między uczniami szkół muzycznych i plastycznych, sąjednocześnie elementami istotnie różniącymi ich od osób nieposiadających artystycznych zdolności.

\section{PROBLEM}

Głównym celem badań jest poznanie różnic w zakresie cech temperamentu i kompetencji społecznych między uzdolnionymi artystycznie adolescentami, których profil zdolności różnicuje typ szkoły artystycznej, w jakiej się kształca (uczniowie szkół muzycznych i plastycznych), a także porównanie ich z uczniami szkół ogólnokształcących, którzy nie wyróżniają się podwyższonym poziomem zdolności muzycznych lub plastycznych. Drugim celem badań jest poznanie powiązań między temperamentem a kompetencjami społecznymi uczniów szkół muzycznych, plastycznych i ogólnokształcących.

Odpowiedzi na pytania badawcze maja na celu stwierdzenie: (1) czy istnieją różnice między uczniami szkół artystycznych (repre- zentującymi podwyższony poziom zdolności muzycznych i plastycznych) a uczniami szkół nieartystycznych w zakresie cech temperamentu i kompetencji społecznych, (2) czy istnieje związek korelacyjny między temperamentem a kompetencjami społecznymi uczniów szkół muzycznych, plastycznych i ogólnokształcących.

$\mathrm{Z}$ uwagi na różnice $\mathrm{w}$ specyfice kształcenia muzycznego i plastycznego można założyć, iż uczniowie tych dwóch typów szkół przejawiać będą zróżnicowany poziom występowania poszczególnych cech składających się na temperament oraz na kompetencje społeczne (por. Chruszczewski, 2009; Nogaj, Owczarz, 2015), a także będą się różnić od uczniów szkół ogólnokształcących, którzy deklarują w swoim wypadku brak występowania i rozwijania zdolności artystycznych. Uczniowie szkół muzycznych szybciej rozpoczynaja profesjonalne kształcenie artystyczne oraz doświadczają zwiększonej liczby trudnych sytuacji i silniejszych emocji podczas prezentacji wykonań muzycznych (Dews, Williams, 1989; Jaślar-Walicka, 1999; Welch, Ockelford, 2009; Manturzewska, 2014) niż uczniowie szkół plastycznych.

Przyjęto następujące hipotezy:

- (H1) uczniowie szkót artystycznych w zakresie cech temperamentu przejawiaja wyższy poziom wrażliwości sensorycznej, aktywności i wytrzymałości niz uczniowie szkót ogólnokształcacych,

- (H2) uczniowie szkót muzycznych w zakresie ekspozycji społecznej przejawiaja wyższy poziom kompetencji społecznych od uczniów szkót plastycznych i ogólnoksztatcacych,

- (H3) istnieje zwiazek między wytrzymatościa $i$ aktywnościa a ekspozycja społeczna u uczniów szkó artystycznych.

\section{METODA BADANIA}

\section{Charakterystyka narzędzi badawczych}

Formalna Charakterystyka Zachowania-Kwestionariusz Temperamentu (FCZ-KT) Bogdana Zawadzkiego i Jana Strelaua (1997) służy do 
pomiaru podstawowych, pierwotnie biologicznie zdeterminowanych cech osobowości, wyodrębnionych jako temperament, w ramach Regulacyjnej Teorii Temperamentu (RTT). W teorii tej zakłada się istnienie cech temperamentu rozumianych jako ogólne wymiary obejmujące czasowe i energetyczne właściwości zachowania. Kwestionariusz przeznaczony jest do badania młodzieży w wieku od 15 lat i osób dorosłych.

Kwestionariusz składa się ze 120 twierdzeń z możliwością zaznaczenia odpowiedzi twierdzącej lub przeczącej. Skale zawarte w FCZ-KT są tożsame z cechami temperamentu wyodrębnionymi w RTT. Każda ze skal zawiera 20 pytań. Skale dotyczą takich cech, jak (Strelau, 2014, s. 332):

- $\quad$ żwawość $(\dot{Z} W)$ - tendencja do szybkiego reagowania, do utrzymywania wysokiego tempa aktywności i do łatwej zmiany z jednego zachowania (reakcji) w inne, odpowiednio do zmian w otoczeniu;

- perseweratywność (PE) - tendencja do kontynuowania i powtarzania zachowań po zaprzestaniu działania bodźca (sytuacji), który to zachowanie wywołał;

- wrażliwość sensoryczna (WS) - zdolność do reagowania na bodźce wywołujące emocje, wyrażająca się dużą wrażliwoścą i niską odpornością emocjonalną;

- reaktywność emocjonalna $(\mathrm{RE})$ - tendencja do intensywnego reagowania na bodźce wywołujące emocje, wyrażająca się dużą wrażliwością i niską odpornością emocjonalną;

- wytrzymalość (WT) - zdolność do adekwatnego reagowania w sytuacjach wymagających długotrwałej lub wysoko stymulującej aktywności oraz w warunkach silnej stymulacji zewnętrznej;

- aktywność (AK) - tendencja do podejmowania zachowań o dużej wartości stymulacyjnej lub do zachowań dostarczających stymulacji zewnętrznej (z otoczenia).

Rzetelność FCZ-KT dla wyniku ogólnego ( $\alpha$ Cronbacha), realizowana na pięciu próbach $(n=2629)$, wśród których byli młodzież i dorośli z różnym poziomem wykształcenia do siedemdziesiątego siódmego roku życia, wynosiła dla poszczególnych skal od $\alpha=.70$ do $\alpha=.87$.

Trafność narzędzia jest satysfakcjonująca. Ogólnie współczynniki korelacji dla wszystkich skal oscylowały wokół wartości $\alpha=.50$ (Zawadzki, Strelau, 1997).

Kwestionariusz Kompetencji Społecznych (KKS) Anny Matczak (2001) jest jednym z nielicznych narzędzi na polskim rynku dotyczącym kompetencji społecznych i jedynym, który umożliwia pomiar kompetencji w zakresie ekspozycji społecznej, istotnej z perspektywy funkcjonowania uczniów szkół artystycznych narażonych na szereg sytuacji związanych z publicznymi prezentacjami. Przeznaczony jest do badania młodzieży i osób dorosłych.

Przyjmując perspektywę psychologii różnic indywidualnych, kompetencje społeczne określa się jako dyspozycję warunkującą efektywne funkcjonowanie w sytuacjach społecznych. Kwestionariusz składa się z 90 pozycji, z czego 60 ma wartość diagnostyczną. Wśród skal wyróżnia się kompetencje w zakresie:

- $\quad$ sytuacji intymnych (I) - warunkujące efektywność zachowań w sytuacjach intymnych, oznaczające bliskie kontakty interpersonalne i związane $\mathrm{z}$ daleko idącym ujawnianiem się (zwierzanie się lub umiejętność słuchania);

- ekspozycji społecznej (ES) - warunkujące efektywność zachowań w sytuacjach ekspozycji społecznej, oznaczające bycie obiektem uwagi i potencjalnej oceny ze strony wielu osób;

- asertywności (A) - warunkujące efektywność zachowań w sytuacjach wymagających asertywności, oznaczające realizowanie własnych celów czy potrzeb poprzez wywieranie wpływu na innych lub opieranie się wpływowi innych.

Rzetelność KKS przeprowadzano w trzech próbach, które stanowili uczniowie, studenci i osoby dorosłe $(n=2235)$, wśród których $49 \%$ to kobiety, a 51\% mężczyźni. Zgodność wewnętrzna obliczona współczynnikiem $\alpha$ Cronbacha miała dla poszczególnych skal we wszystkich próbach wartość na ogół przekraczającą $\alpha=.80$. Trafność narzędzia została określona jako satysfakcjonująca. 


\section{Charakterystyka badanej grupy i procedura badania}

W badaniach uczestniczyło 354 uczniów, wśród których 45\% stanowili uczniowie szkół muzycznych $(n=156$; dziewczęta $=99$; chłopcy $=57$; wiek $M=17.95, S D=1.15), 28 \%$ uczniowie szkół plastycznych $(n=100$; dziewczęta $=79$; chłopcy $=21$; wiek $M=16.99$, $S D=.78)$, a 27\% uczniowie szkół ogólnokształcących $(n=98$; dziewczęta $=54$; chłopcy $=$ 44 ; wiek $M=16.64, S D=.79$ ). Zauważalna jest pewna dysproporcja między liczbą dziewcząt a chłopców kształcących się w szkołach artystycznych. Jest to tendencja typowa dla populacji uczniów szkół artystycznych, która została potwierdzona także $w$ innych badaniach (por. Chruszczewski, 2004), a także przez odpowiednie dane Głównego Urzędu Statystycznego. Wiek badanych wahał się od szesnastu do dziewiętnastu lat. Wszyscy badani byli uczniami szkół średniego poziomu kształcenia o profilu licealnym. W grupie uczniów szkół ogólnokształcących nie kontrolowano zdolności kierunkowych związanych $\mathrm{z}$ nauką wybranych przedmiotów z zakresu nauk humanistycznych lub ścisłych. Uczniowie ci stanowili grupe porównawczą, co do której stwierdzono na poziomie deklaratywnym, że nie wyróżnia się zdolnościami artystycznymi.

Badania realizowano od stycznia do marca 2013 roku. Przeprowadzono je w formie grupowej, w obecności autora badań. Badani byli proszeni o anonimowe wypełnienie kwestionariusza Formalna Charakterystyka Zachowania - Kwestionariusz Temperamentu oraz Kwestionariusza Kompetencji Społecznych. Badane grupy obejmowały od 20 do 30 osób, a czas realizacji procedury nie przekraczał 45 minut.

Do obliczania wyników badań posłużono się oprogramowaniem STATISTICA. Wyniki testu W Shapiro-Wilka wykazały brak rozkładu normalnego weryfikowanych zmiennych. Do porównań międzygrupowych wykorzystano analizę ANOVA (ang. Analysis of Variance) Kruskala-Wallisa. Następnie, aby zweryfikować występowanie związku między zmienny- mi, wykorzystano korelację rang Spearmana. Zbudowano również model wielowymiarowej analizy korespondencji MCA (ang. Multiple Correspondence Analysis). Celem tego modelu było ukazanie, w jakich skupieniach występują poziomy cech temperamentu oraz kompetencji społecznych uczniów szkół artystycznych i nieartystycznych. Aby można było wykonać tę analizę, dokonano podziału mierzonych zmiennych na dwa poziomy - niższy ,N” i wyższy „W” według wzoru (1). Wzór ten zastosowano, ponieważ - mimo braku istotności zgodności $\mathrm{z}$ rozkładem normalnym mierzonych zmiennych - rozkłady tychże zmiennych wykazały zbieżność $\mathrm{z}$ rozkładem normalnym. W ten sposób uniknięto tzw. nadmiernego dopasowania do zmiennych z próby.

$$
\Phi_{0,1}(x)=\Phi(x)=\left\{\begin{array}{l}
\frac{1}{\sqrt{2 \pi}} \exp \left(-\frac{x^{2}}{2}\right)<0 \Rightarrow L \\
\frac{1}{\sqrt{2 \pi}} \exp \left(-\frac{x^{2}}{2}\right) \geq 0 \Rightarrow H
\end{array}\right.
$$

\section{WYNIKI}

\section{Cechy temperamentu i kompetencje społeczne uczniów szkół artystycznych i nieartystycznych}

Aby poznać temperament i kompetencje społeczne uczniów szkół muzycznych i plastycznych, a także uchwycić różnice w tym zakresie w zestawieniu z uczniami szkół nieartystycznych, przeprowadzono analizy z uwzględnieniem statystyk podstawowych. W tabeli 1 przedstawiono wyniki średnie, mediany, odchylenia standardowe, skośność, kurtozę oraz wartość minimalną i maksymalną otrzymanych wyników z uwzględnieniem podziału uczniów na grupy wynikające ze specjalności kształcenia.

Wyniki podane w tabeli 1 pozwalają odpowiedzieć na pytanie, jaki jest poziom nasilenia cech temperamentu i kompetencji społecznych u uczniów szkół muzycznych, plastycznych i ogólnokształcących. Interpretacja jakościowa wyników średnich wskazuje, że w zakresie 
Tabela 1. Temperament i kompetencje społeczne uczniów szkół muzycznych, plastycznych i ogólnokształcących (statystyki opisowe)

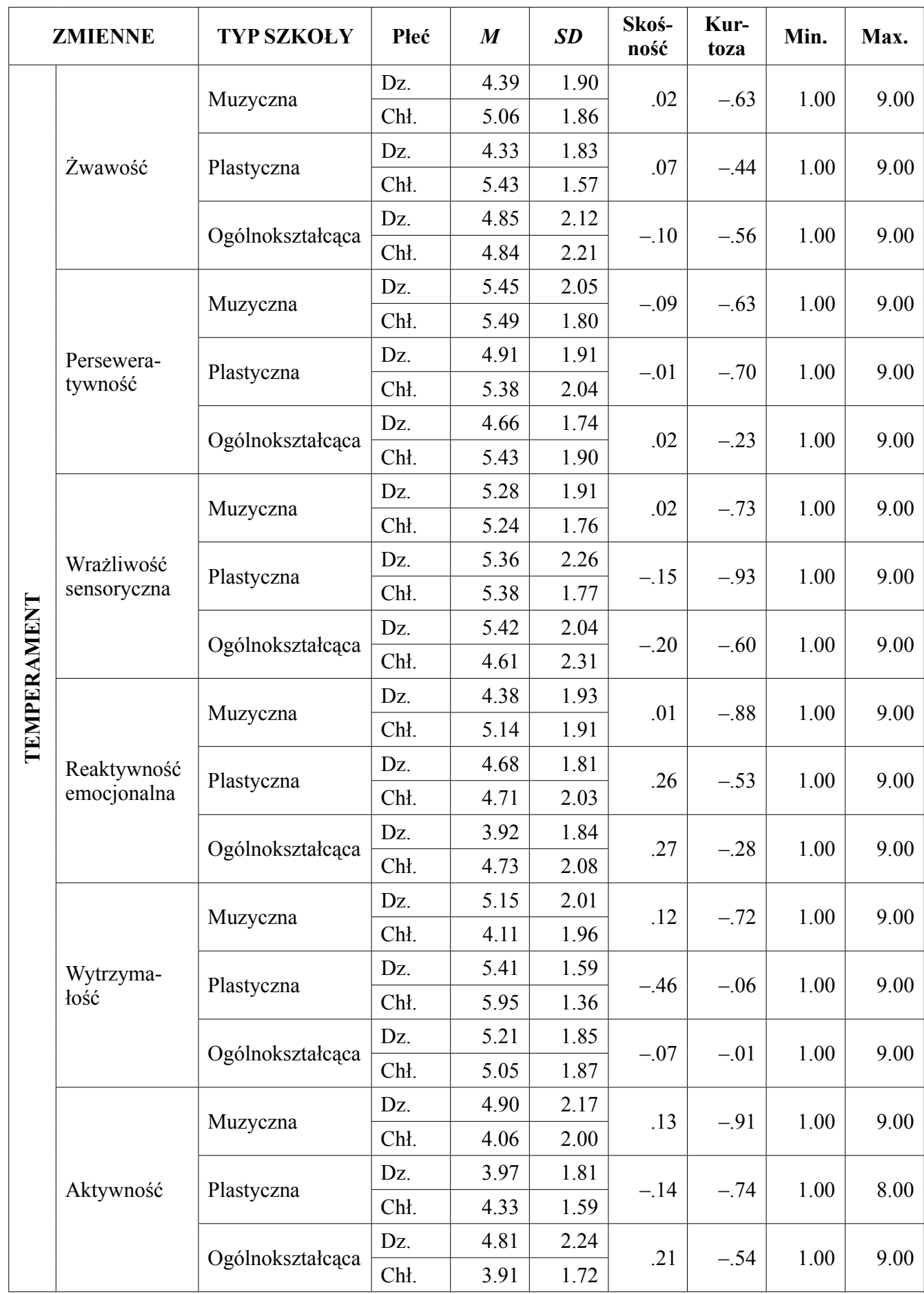




\begin{tabular}{|c|c|c|c|c|c|c|c|c|c|}
\hline \multicolumn{2}{|r|}{ ZMIENNE } & TYP SZKOLY & Pleć & $M$ & $S D$ & $\begin{array}{l}\text { Skoś- } \\
\text { nośćc }\end{array}$ & $\begin{array}{l}\text { Kur- } \\
\text { toza }\end{array}$ & Min. & Max. \\
\hline \multirow{18}{*}{ 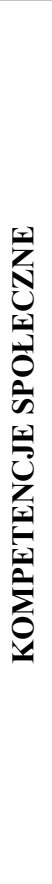 } & \multirow{6}{*}{ Intymność } & \multirow{2}{*}{ Muzyczna } & Dz. & 6.06 & 2.07 & \multirow{2}{*}{-.31} & \multirow{2}{*}{-.28} & \multirow{2}{*}{1.00} & \multirow{2}{*}{9.00} \\
\hline & & & Chł. & 5.31 & 1.62 & & & & \\
\hline & & \multirow{2}{*}{ Plastyczna } & Dz. & 5.37 & 1.98 & \multirow{2}{*}{-.24} & \multirow{2}{*}{-.36} & \multirow{2}{*}{1.00} & \multirow{2}{*}{9.00} \\
\hline & & & Chł. & 4.90 & 2.02 & & & & \\
\hline & & \multirow{2}{*}{ Ogólnokształcąca } & Dz. & 5.22 & 1.89 & \multirow{2}{*}{.10} & \multirow{2}{*}{-.03} & \multirow{2}{*}{1.00} & \multirow{2}{*}{10.00} \\
\hline & & & Chł. & 5.28 & 2.15 & & & & \\
\hline & \multirow{6}{*}{$\begin{array}{l}\text { Ekspozycja } \\
\text { społeczna }\end{array}$} & \multirow{2}{*}{ Muzyczna } & Dz. & 5.86 & 2.29 & \multirow{2}{*}{-.07} & \multirow{2}{*}{-.65} & \multirow{2}{*}{1.00} & \multirow{2}{*}{10.00} \\
\hline & & & Chł. & 5.61 & 2.13 & & & & \\
\hline & & \multirow{2}{*}{ Plastyczna } & Dz. & 4.66 & 2.01 & \multirow{2}{*}{.41} & \multirow{2}{*}{-.21} & \multirow{2}{*}{1.00} & \multirow{2}{*}{10.00} \\
\hline & & & Chł. & 5.90 & 2.28 & & & & \\
\hline & & \multirow{2}{*}{ Ogólnokształcąca } & Dz. & 5.73 & 2.38 & \multirow{2}{*}{-.05} & \multirow{2}{*}{-.88} & \multirow{2}{*}{1.00} & \multirow{2}{*}{10.00} \\
\hline & & & Chł. & 5.88 & 2.52 & & & & \\
\hline & \multirow{6}{*}{ Asertywność } & Mu & Dz. & 5.81 & 2.18 & 02 & 10 & 100 & 1000 \\
\hline & & Muzyczna & Chł. & 5.27 & 1.79 & ? & -.49 & 1.00 & 10.00 \\
\hline & & Plastyczna & Dz. & 5.44 & 2.05 & & 0 & 100 & 1000 \\
\hline & & r Tastyczira & Chł. & 5.57 & 1.94 & & & 1.00 & 10.00 \\
\hline & & $\mathrm{Oc}_{0}$ & Dz. & 5.68 & 1.94 & 0 & & 00 & 00. \\
\hline & & UgomUKSZLateącd & Cht. & 6.08 & 2.04 & .19 & -.50 & 1.00 & 10.00 \\
\hline
\end{tabular}

Źródło: opracowanie własne.

każdej zmiennej uczniów wszystkich typów szkół charakteryzuje przeciętne nasilenie poszczególnych cech temperamentu i kompetencji społecznych. Najwyższe rozproszenie wyników zauważalne jest w zakresie ekspozycji społecznej. Ujemne wyniki kurtozy świadczą o częstym występowaniu skrajnych wyników w badanych grupach. Wyższe wyniki kurtozy występują częściej w grupie uczniów szkół artystycznych niż w grupie uczniów szkół ogólnokształcących. Odwrotna tendencja zaznaczyła się w przypadku ekspozycji społecznej.

Aby zweryfikować występowanie istotnych różnic, a tym samym odpowiedzieć rozstrzygająco na pytania, czy i jakie różnice występują między uczniami szkół muzycznych, plastycznych i ogólnokształcących, podjęto dalsze analizy.
Różnice w zakresie cech temperamentu i kompetencji spolecznych u uczniów szkół artystycznych i nieartystycznych

W poniższych analizach statystycznych w pierwszej kolejności sprawdzono, czy typ szkoły oraz płeć badanych osób różnicuje, w interakcji ze sobą, wartości badanych zmiennych, czyli cech temperamentu i kompetencji społecznych. $\mathrm{W}$ tym miejscu, ze względu na zbieżność $\mathrm{z}$ rozkładem normalnym, zastosowano dwuczynnikową analizę ANOVA. Na poziomie istotności $\alpha=.05$ stwierdzono, że nie zachodzą istotne różnice we wskazanych zmiennych (tabela 2). Interakcja płci i typu kształcenia nie różnicuje istotnie uczniów szkół muzycznych, plastycznych i ogólnokształcących.

Skoncentrowano się zatem na ocenie różnic między uczniami różnego typu szkół, 
Tabela 2. Różnice w cechach temperamentu i kompetencji społecznych wśród dziewcząt i chłopców kształcących się w szkołach muzycznych, plastycznych i ogólnokształcących (analiza wariancji ANOVA dwuczynnikowa)

\begin{tabular}{|c|c|c|c|c|c|c|}
\hline \multicolumn{3}{|c|}{ ZMIENNE } & $\mathbf{F}$ & df & $p$ & $\eta^{2}$ \\
\hline \multirow{18}{*}{ 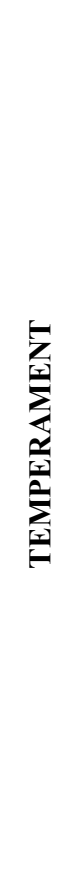 } & \multirow{3}{*}{ Żwawość } & Płeć & 6.24 & 1 & $.02 * *$ & .02 \\
\hline & & Typ szkoły & .19 & 2 & .83 & .01 \\
\hline & & Płeć a typ szkoły & 1.72 & 2 & .18 & .01 \\
\hline & \multirow{3}{*}{ Perseweratywność } & Płeć & 3.39 & 1 & $.07 *$ & .01 \\
\hline & & Typ szkoły & 1.52 & 2 & .22 & .01 \\
\hline & & Płeć a typ szkoły & 1.04 & 2 & .35 & .01 \\
\hline & \multirow{3}{*}{ Wrażliwość sensoryczna } & Płeć & 1.22 & 1 & .27 & .01 \\
\hline & & Typ szkoły & .68 & 2 & .51 & .01 \\
\hline & & Płeć a typ szkoły & 1.2 & 2 & .31 & .01 \\
\hline & \multirow{3}{*}{ Reaktywność emocjonalna } & Płeć & 5.29 & 1 & $.02 * *$ & .02 \\
\hline & & Typ szkoły & 1.53 & 2 & .22 & .01 \\
\hline & & Płeć a typ szkoły & .97 & 2 & .38 & .01 \\
\hline & \multirow{3}{*}{ Wytrzymałość } & Płeć & .29 & 1 & .59 & .01 \\
\hline & & Typ szkoły & 5.35 & 2 & $.01 * *$ & .03 \\
\hline & & Płeć a typ szkoły & 2.77 & 2 & .06 & .02 \\
\hline & \multirow{3}{*}{ Aktywność } & Płeć & 3.65 & 1 & $.06^{*}$ & .01 \\
\hline & & Typ szkoły & .59 & 2 & .56 & .01 \\
\hline & & Płeć a typ szkoły & 2.43 & 2 & $.09 *$ & .01 \\
\hline \multirow{9}{*}{ 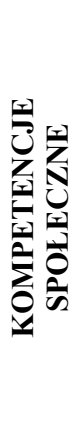 } & \multirow{3}{*}{ Intymność } & Płeć & .35 & 1 & .85 & .00 \\
\hline & & Typ szkoły & 1.08 & 2 & .35 & .01 \\
\hline & & Płeć a typ szkoły & 2.61 & 2 & $.08 *$ & .02 \\
\hline & \multirow{3}{*}{ Ekspozycja społeczna } & Płeć & 1.69 & 1 & .20 & .01 \\
\hline & & Typ szkoły & 1.14 & 2 & .32 & .01 \\
\hline & & Płeć a typ szkoły & 2.52 & 2 & $.08^{*}$ & .02 \\
\hline & \multirow{3}{*}{ Asertywność } & Płeć & .00 & 1 & 1.00 & .00 \\
\hline & & Typ szkoły & .68 & 2 & .51 & .00 \\
\hline & & Płeć a typ szkoły & 1.31 & 2 & .27 & .01 \\
\hline
\end{tabular}

* Istotność na poziomie tendencji statystycznej między $p>.05$ a $p<.1$

** Współczynnik istotności $p<.05$

Źródło: opracowanie własne.

wykorzystując do tego celu analizę ANOVA Kruskala-Wallisa. Wyniki tej analizy zamieszczono w tabeli 3.

Uzyskane wyniki wykazały, że uczniowie kształcący się w jednym z trzech badanych typów szkół różnią się między sobą w zakre- sie temperamentu w wymiarze cechy, jaką jest wytrzymałość, a w zakresie kompetencji społecznych w wymiarze ekspozycji społecznej. Aby zweryfikować szczegółowe różnice między badanymi grupami uczniów, wykonano test porównań wielokrotnych. Uczniowie 
Tabela 3. Różnice w cechach temperamentu i kompetencji społecznych wśród uczniów szkół muzycznych, plastycznych i ogólnokształcących (analiza ANOVA rang Kruskala-Wallisa)

\begin{tabular}{|c|c|c|c|c|c|c|}
\hline \multicolumn{2}{|r|}{ ZMIENNE } & TYP SZKOLY & $M$ & $S D$ & $M D$ & $\begin{array}{c}\text { ANOVA rang } \\
\text { Kruskala-Wallisa }\end{array}$ \\
\hline \multirow{18}{*}{ 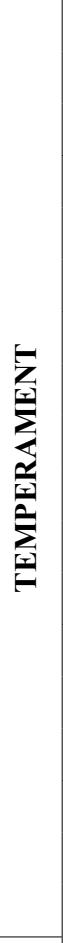 } & \multirow{3}{*}{ Żwawość } & Muzyczna & 4.62 & 4.00 & 1.91 & \multirow{3}{*}{$\begin{array}{l}\mathrm{H}(2, \mathrm{~N}=345)=1.322 \\
p=.516\end{array}$} \\
\hline & & Plastyczna & 4.57 & 5.00 & 1.82 & \\
\hline & & Ogólnokształcąca & 4.85 & 5.00 & 2.15 & \\
\hline & \multirow{3}{*}{ Perseweratywność } & Muzyczna & 5.46 & 5.00 & 1.96 & \multirow{3}{*}{$\begin{array}{l}\mathrm{H}(2, \mathrm{~N}=345)=4.313 \\
p=.116\end{array}$} \\
\hline & & Plastyczna & 5.01 & 5.00 & 1.94 & \\
\hline & & Ogólnokształcąca & 5.01 & 5.00 & 1.85 & \\
\hline & \multirow{3}{*}{ Wrażliwość sensoryczna } & Muzyczna & 5.26 & 5.00 & 1.85 & \multirow{3}{*}{$\begin{array}{l}\mathrm{H}(2, \mathrm{~N}=345)=0.817 \\
p=.665\end{array}$} \\
\hline & & Plastyczna & 5.36 & 6.00 & 2.16 & \\
\hline & & Ogólnokształcąca & 5.05 & 5.00 & 2.20 & \\
\hline & \multirow{3}{*}{ Reaktywność emocjonalna } & Muzyczna & 4.64 & 5.00 & 1.95 & \multirow{3}{*}{$\begin{array}{l}\mathrm{H}(2, \mathrm{~N}=345)=2.337 \\
p=.311\end{array}$} \\
\hline & & Plastyczna & 4.69 & 4.00 & 1.84 & \\
\hline & & Ogólnokształcąca & 4.29 & 4.00 & 1.98 & \\
\hline & \multirow{3}{*}{ Wytrzymałość } & Muzyczna & 4.90 & 5.00 & 2.01 & \multirow{3}{*}{$\begin{array}{l}* \mathrm{H}(2, \mathrm{~N}=345)=8.062 ; \\
p=.018\end{array}$} \\
\hline & & Plastyczna & 5.53 & 6.00 & 1.55 & \\
\hline & & Ogólnokształcąca & 5.13 & 5.00 & 1.85 & \\
\hline & \multirow{3}{*}{ Aktywność } & Muzyczna & 4.61 & 5.00 & 2.14 & \multirow{3}{*}{$\begin{array}{l}\mathrm{H}(2, \mathrm{~N}=345)=3.393 \\
p=.183\end{array}$} \\
\hline & & Plastyczna & 4.05 & 4.00 & 1.76 & \\
\hline & & Ogólnokształcąca & 4.40 & 4.00 & 2.06 & \\
\hline \multirow{9}{*}{ 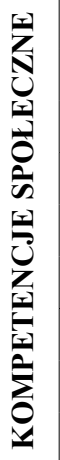 } & \multirow{3}{*}{ Intymność } & Muzyczna & 5.79 & 6.00 & 1.95 & \multirow{3}{*}{$\begin{array}{l}\mathrm{H}(2, \mathrm{~N}=311)=4.245 \\
p=.120\end{array}$} \\
\hline & & Plastyczna & 5.48 & 6.00 & 1.99 & \\
\hline & & Ogólnokształcąca & 5.24 & 5.00 & 1.98 & \\
\hline & \multirow{3}{*}{ Ekspozycja społeczna } & Muzyczna & 5.77 & 6.00 & 2.24 & \multirow{3}{*}{$\begin{array}{l}* \mathrm{H}(2, \mathrm{~N}=311)=10.383 \\
p=.006\end{array}$} \\
\hline & & Plastyczna & 4.92 & 5.00 & 2.12 & \\
\hline & & Ogólnokształcąca & 5.79 & 6.00 & 2.42 & \\
\hline & \multirow{3}{*}{ Asertywność } & Muzyczna & 5.62 & 6.00 & 2.07 & \multirow{3}{*}{$\begin{array}{l}\mathrm{H}(2, \mathrm{~N}=311)=0.891 \\
p=.641\end{array}$} \\
\hline & & Plastyczna & 5.47 & 6.00 & 2.02 & \\
\hline & & Ogólnokształcąca & 5.84 & 6.00 & 1.98 & \\
\hline
\end{tabular}

Źródło: opracowanie własne.

szkół plastycznych są istotnie statystycznie $(p=.015)$ bardziej wytrzymali od uczniów szkół muzycznych. Z kolei w zakresie kompetencji społecznych są częściej mniej gotowi do ekspozycji społecznych niż uczniowie szkół muzycznych $(p=.008)$ oraz uczniowie kształcący się w liceach ogólnokształcących $(p=.047)$.

Otrzymane wyniki pozwalają jedynie na częściowe potwierdzenie hipotezy pierwszej i drugiej. Uczniowie szkół artystycznych różnią się od uczniów szkół nieartystycznych jedynie 
poziomem wytrzymałości, natomiast wrażliwość sensoryczna oraz aktywność nie różnicują badanych grup uczniów. W grupie uczniów szkół artystycznych przejawiających wyższy poziom wytrzymałości znaleźli się uczniowie szkół plastycznych. W zakresie kompetencji społecznych uczniowie szkół muzycznych nie wyróżniają się na tle pozostałych grup uczniów jako posiadający najwyższy poziom umiejętności w zakresie ekspozycji społecznej. Natomiast uczniowie szkół plastycznych, w porównaniu z uczniami szkół muzycznych i ogólnokształcących, przejawiają istotnie niższy poziom kompetencji w tym obszarze.
W celu lepszego zobrazowania struktury powiązania zmiennych zastosowano wielowymiarową analizę korespondencji MCA. Wyniki przedstawiono w tabeli 4 oraz na rysunku 1.

Analiza korespondencji ukazała, że potencjalnie dziewczęta $\mathrm{z}$ liceów ogólnokształcących (stanowiące $\mathrm{w}$ niniejszych badaniach grupę porównawczą, deklarującą brak zdolności muzycznych i/lub plastycznych) będą miały ze zbliżonym prawdopodobieństwem niższą lub wyższą wrażliwość sensoryczną. Dla tych dziewcząt, a szczególnie charakteryzujących się wyższą wrażliwością sensoryczną, najbardziej prawdopodobny jest niższy poziom perseweratywności,

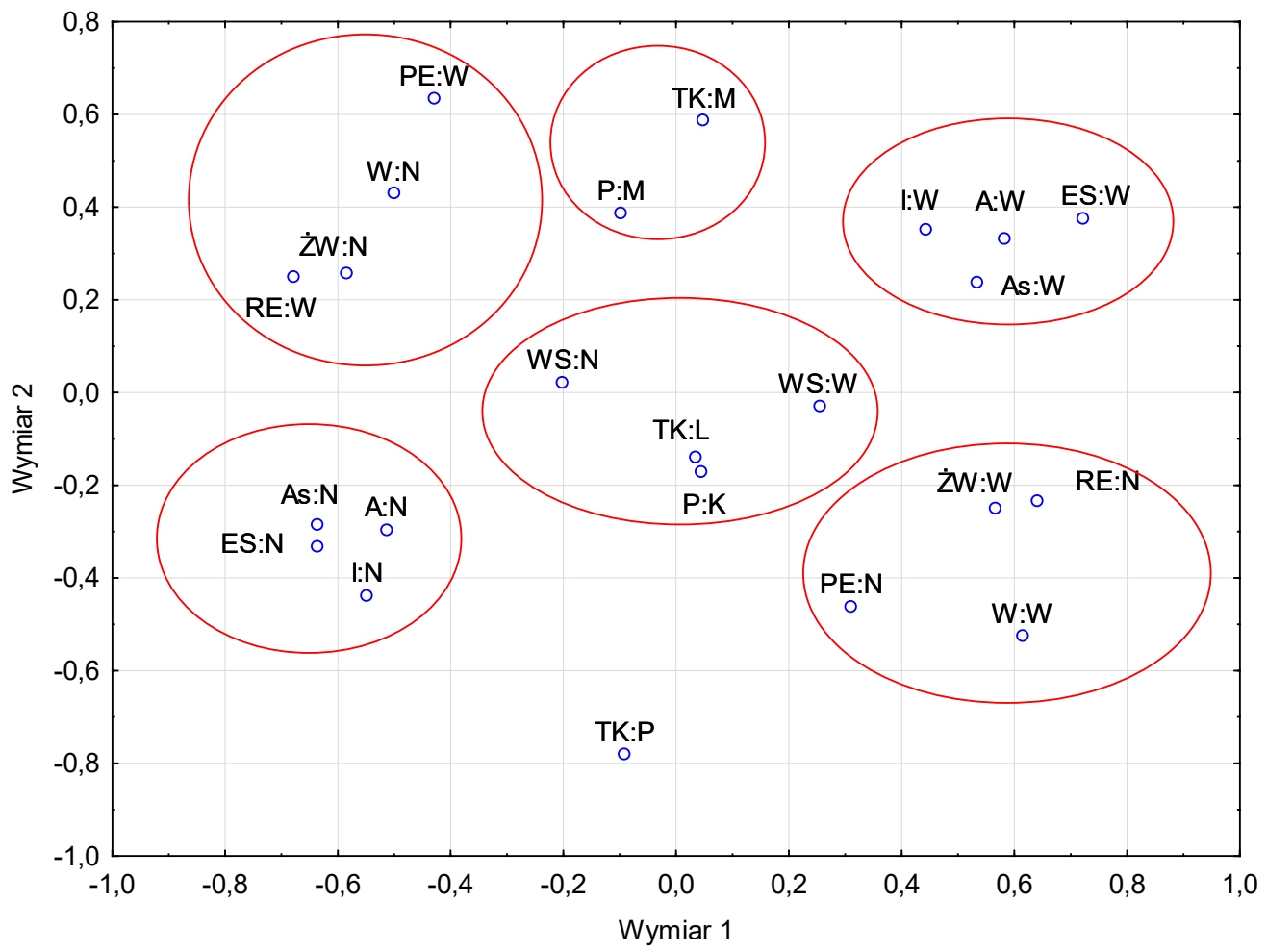

Legenda: (płeć) P:M - mężczyzna, P:K - kobieta, (typ kształcenia) TK:M - uczniowie szkół muzycznych, TK:L - uczniowie liceum ogólnokształcącego, TK:P - uczniowie szkół plastycznych, (podział na wyniki wysokie i niskie) N - wynik niższy, W - wynik wyższy, (temperament) ŻW - żwawość, PE - perserwatywność, WS - wrażliwość społeczna, W - wytrzymałość, A - aktywność, RE - reaktywność emocjonalna, (kompetencje społeczne) I - intymność, ES - ekspozycja społeczna, A - asertywność.

Rysunek 1. Wielowymiarowa analiza korespondencji MCA

Źródło: opracowanie własne. 
ชิ

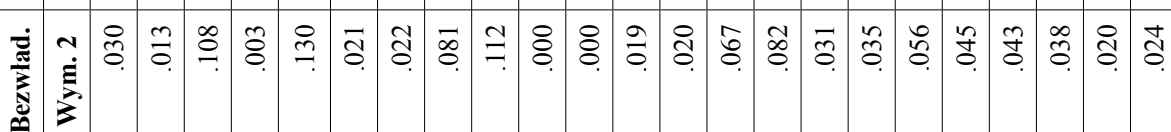

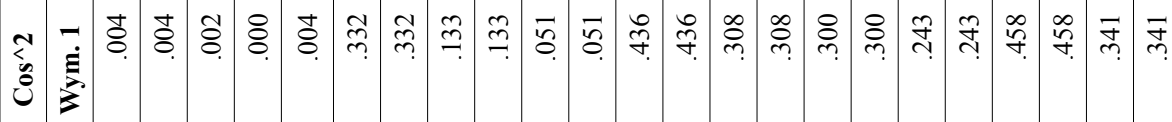

产

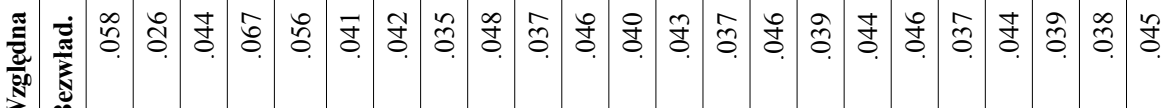

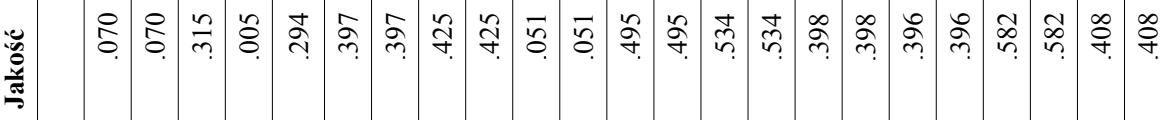

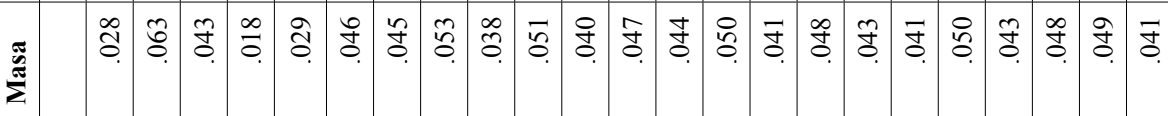

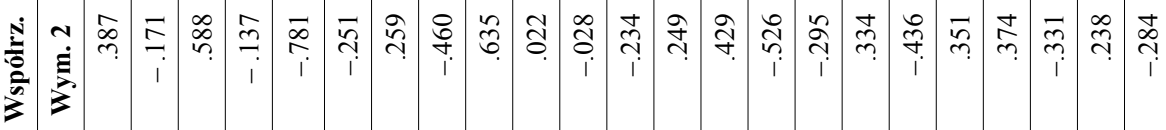

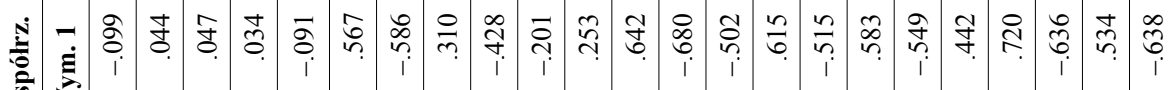

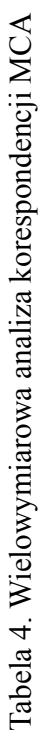

:

王

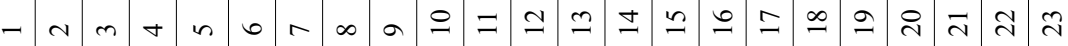

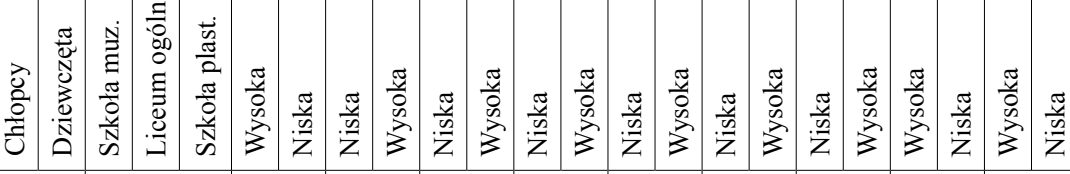

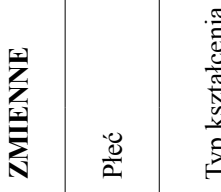

\begin{tabular}{|c|c|c|c|c|c|c|c|c|}
\hline 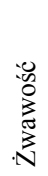 & 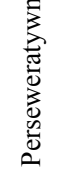 & 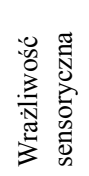 & 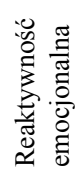 & 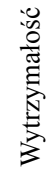 & 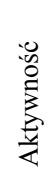 & $\begin{array}{l}\text { 总 } \\
\text { 泀 } \\
\text { 总 }\end{array}$ & 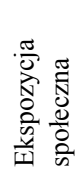 & 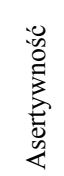 \\
\hline \multicolumn{6}{|c|}{ LNAWVYGAW'L } & \multicolumn{3}{|c|}{$\begin{array}{c}\text { ANZPATOdS } \\
\text { AFONGLAdWOY }\end{array}$} \\
\hline
\end{tabular}

$\frac{\dot{0}}{\frac{\pi}{3}}$ 
wyższy poziom żwawości, a także, z większym prawdopodobieństwem, niższy poziom ekspozycji społecznej. Analiza korespondencji wskazała także na kształtowanie się pewnego układu w wypadku chłopców ze szkół muzycznych. Z większym prawdopodobieństwem będą mieli wyższy poziom perseweratywności, niższy wytrzymałości i żwawości oraz wyższy poziom reaktywności emocjonalnej. Warto zauważyć również, iż osoby z wyższym poziomem kompetencji społecznych w zakresie intymności z dużym prawdopodobieństwem cechują się wyższym poziomem aktywności, są bardziej asertywne oraz mają wyższe kompetencje w ekspozycji społecznej. Przeciwstawny obraz występuje u osób przejawiających niższy poziom intymności.

\section{Temperament a kompetencje społeczne uczniów szkół muzycznych, plastycznych i ogólnokształcących}

Wyniki zawarte w tabeli 5 wskazują na występowanie zależności między temperamentem a kompetencjami społecznymi, odrębnie w trzech badanych grupach.
Analiza korelacyjna współczynników Spearmana powala zauważyć, że u uczniów wszystkich typów szkół występuje pozytywny związek między aktywnością (rozumianą jako cecha temperamentu) a wszystkimi trzema rodzajami kompetencji społecznych.

Najsilniejsze korelacje zaznaczyły się między kompetencją w zakresie ekspozycji społecznej a takimi cechami temperamentu, jak reaktywność emocjonalna i aktywność. W grupach uczniów kształcących się w szkołach muzycznych i plastycznych występuje przeciętny poziom korelacji między tymi zmiennymi, w grupie uczniów ze szkół ogólnokształcących zaś stwierdzono wysoki poziom korelacji między aktywnością a ekspozycją społeczną. Można zatem powiedzieć, że im wyższy poziom aktywności przejawiają uczniowie, tym wyższy jest ich poziom kompetencji społecznych w zakresie publicznej ekspozycji. Współczynniki korelacji potwierdzaja, że grupy uczniów szkół artystycznych i uczniów szkoły ogólnokształcącej różnią się w tym zakresie $(p=.01)$.

W każdej z badanych grup na przeciętnym poziomie ujawnia się korelacja między aktywnoś-

Tabela 5. Związek między temperamentem a kompetencjami społecznymi w trzech grupach uczniów, kształcących się w szkołach muzycznych, plastycznych i ogólnokształcących (korelacje Spearmana)

\begin{tabular}{|c|c|c|c|c|c|c|c|}
\hline Typ szkoły & $\begin{array}{l}\text { Kompetencje } \\
\text { społeczne }\end{array}$ & 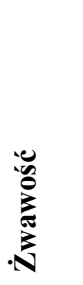 & 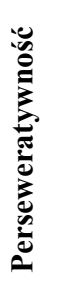 & 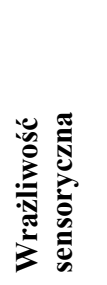 & 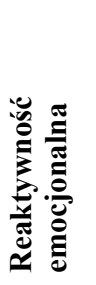 & 总 & 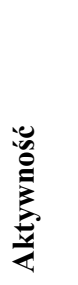 \\
\hline \multirow{3}{*}{$\begin{array}{l}\text { Uczniowie szkół } \\
\text { muzycznych }\end{array}$} & Intymność & .13 & -.09 & .04 & -.27 & .12 & .2 \\
\hline & Ekspozycja społ. & .32 & -.2 & .13 & -.45 & .29 & .46 \\
\hline & Asertywność & .27 & -.26 & .05 & -.31 & .09 & .32 \\
\hline \multirow{3}{*}{$\begin{array}{l}\text { Uczniowie szkół } \\
\text { plastycznych }\end{array}$} & Intymność & .18 & .10 & .01 & -.22 & -.01 & .35 \\
\hline & Ekspozycja społ. & .25 & .01 & .11 & -.44 & .20 & .48 \\
\hline & Asertywność & .13 & -.03 & .12 & -.41 & .04 & .42 \\
\hline \multirow{3}{*}{$\begin{array}{l}\text { Uczniowie szkół } \\
\text { ogólnokształcących }\end{array}$} & Intymność & .07 & -.05 & .18 & -.17 & .17 & .31 \\
\hline & Ekspozycja społ. & .3 & -.25 & .15 & -.49 & .36 & .71 \\
\hline & Asertywność & .24 & -.22 & .05 & -.38 & .4 & .47 \\
\hline
\end{tabular}

Źródło: opracowanie własne. 
cią a asertywnością, jednak poziom korelacji nie różnicuje uczniów kształcących się w szkołach muzycznych, plastycznych i ogólnokształcących.

Zauważalne są także ujemne korelacje między reaktywnością emocjonalną a poszczególnymi kompetencjami społecznymi we wszystkich grupach uczniów. Przeciętną siłę związku można zauważyć między reaktywnością emocjonalną a kompetencją w zakresie ekspozycji społecznej w grupie uczniów szkół zarówno muzycznych, plastycznych, jak i ogólnokształcących. Im niższy poziom reaktywności emocjonalnej, tym wyższy poziom kompetencji w sytuacjach intymnych, w sytuacjach ekspozycji publicznej i w sytuacjach wymagających asertywności. Na słabym poziomie występuje także korelacja między wytrzymałością a kompetencjami społecznymi w zakresie ekspozycji społecznej w każdej $\mathrm{z}$ badanych grup uczniów. Zauważono tendencję, że im wyższy poziom wytrzymałości, tym wyższy poziom kompetencji w sytuacjach publicznych. Perseweratywność koreluje ujemnie, na słabym poziomie, tylko w grupie uczniów szkół muzycznych. Im niższy przejawiają oni poziom perseweratywności, tym wyższe są ich kompetencje społeczne w sytuacjach intymnych, w sytuacjach ekspozycji społecznej oraz w sytuacjach wymagających asertywności.

We wszystkich badanych grupach uczniów żwawość koreluje dodatnio na poziomie słabym z kompetencjami w zakresie ekspozycji społecznej. W grupie uczniów szkół muzycznych żwawość koreluje także dodatnio z asertywnością. Jedynie wrażliwość sensoryczna nie ma związku z kompetencjami społecznymi $\mathrm{w}$ żadnej z badanych grup.

Powyższe analizy statystyczne pozwalają na potwierdzenie związku między temperamentem a kompetencjami społecznymi u uczniów szkół muzycznych i plastycznych, jednakże w zdecydowanej większości związki występujące między tymi zmiennymi nie różnicują istotnie uczniów kształcących się w różnych typach szkół. Związek między wytrzymałością i aktywnością a ekspozycją społeczną nie jest charakterystyczny tylko dla uczniów szkół muzycznych. Uczniowie szkół ogólnokształcących także charakteryzują się współwystępowaniem tych cech.

\section{DYSKUSJA}

Z uwagi na fakt, że osoby badane są na etapie późnej adolescencji, założono, iż profil kształcenia, jaki reprezentuja, jest jednoznaczny z posiadaniem podwyższonego poziomu zdolności artystycznych (w przypadku uczniów szkół muzycznych lub plastycznych) lub z brakiem takich zdolności (w przypadku uczniów szkół ogólnokształcących, którzy jednocześnie zadeklarowali brak doświadczeń w zakresie rozwoju własnych uzdolnień artystycznych). Okres późnej adolescencji zbiega się z fazq integracji charakterystyczną dla edukacji muzycznej (Jaślar-Walicka, 1999; Nogaj, 2014; Sosniak, 1990), która wyróżnia się: (1) wysokim poziomem dojrzałości ucznia w zakresie motywacji skierowanej na świadomy rozwój własnych uzdolnień muzycznych, (2) umiejętnością współpracy $\mathrm{w}$ relacji z nauczycielem artystą i (3) stabilizowaniem się tożsamości w roli młodego/przyszłego artysty. Założono zatem, że cechy temperamentu i kompetencje społeczne ujmowane $z$ perspektywy rozwojowej są ustabilizowane, a zaznaczające się ewentualne zróżnicowanie w funkcjonowaniu uczniów o różnym profilu uzdolnień artystycznych jest efektem specyfiki ich zdolności, rozwijanych w zupełnie odmiennych systemach kształcenia artystycznego. Przedstawione wyniki badań pozwalają zauważyć występowanie pewnych charakterystycznych różnic w funkcjonowaniu uczniów szkół muzycznych, plastycznych i ogólnokształcących.

Zgodnie z przewidywaniami uczniowie szkół artystycznych charakteryzują się wyższym poziomem wytrzymałości niż uczniowie szkół ogólnokształcących. Jednak zaskakujące okazało się, że to uczniowie szkół plastycznych przejawiają wyższy poziom wytrzymałości niż uczniowie szkół muzycznych. Powszechnie zakłada się, iż konieczność regularnego treningu muzycznego wzmacnia wytrzymałość psychofizyczną i uczniowie szkół muzycznych rozwijają w sobie tę cechę niejako przy okazji specyfiki kształcenia muzycznego (por. Ericsson, Krampe, Tesch-Römer, 1993; Ericsson, 2006). Otrzymane wyniki badań ujawniły, że to jednak uczniowie szkół plastycznych są bardziej wytrzymali 
i gotowi do intensywnej pracy niż uczniowie szkół muzycznych. Pojawia się pytanie, czy uczniowie szkół plastycznych byli bardziej wytrzymali, czy też stali się tacy ze względu na specyfikę edukacji artystycznej. Obserwacja środowiska uczniów szkół plastycznych pozwala wysnuć wniosek, iż liczba obowiązków, w tym zadań artystycznych krótko- i długoterminowych, jest tak duża, iż wymaga bardzo wysokiego poziomu mobilizacji wszystkich sił psychicznych do realizacji owych zadań, co stanowi dla uczniów uzdolnionych plastycznie swoisty trening wytrzymałości. Nie oznacza to, że uczniowie szkół muzycznych mają mniej obowiązków i przez to mogą być mniej wytrzymali. Jednak temporalność sztuki muzycznej nakłada na uczniów większe ograniczenia czasowe, także te związane z procesem ćwiczenia. Uczniowie szkół plastycznych często bardziej rozkładają swoją pracę w czasie, dążą do doskonałości, permanentnie poprawiając swoje wytwory (niejednokrotnie nocami) i pomimo dużego poziomu zmęczenia dążą do jak najlepszego i oryginalnego efektu, co może w konsekwencji być przyczyną ich podwyższonego poziomu wytrzymałości.

Jednak to uczniowie szkół plastycznych wyróżniają się zdecydowanie niższym poziomem kompetencji w zakresie ekspozycji społecznej w porównaniu z uczniami szkół muzycznych i ogólnokształcących. Otrzymany wynik ma swoje uzasadnienie w specyfice doświadczeń uczniów szkół plastycznych, którzy zdecydowanie rzadziej niż uczniowie szkół muzycznych występuja publicznie. Jest to związane także $\mathrm{z}$ faktem, iż publiczne wystąpienia osób uzdolnionych plastycznie nie wiążą się z koniecznością zaprezentowania własnych zdolności w rzeczywistym czasie występu. Artyści plastycy publicznie prezentują/eksponują swoje dzieło, a stres, jakiego doświadczają przy takich okazjach, jest raczej związany z tym, jak ich praca zostanie odebrana przez widzów (por. Chruszczewski, 2009; Furnham, Crump, 2013), a nie z ekspozycją samego siebie. Choć badani uczniowie szkół muzycznych nie wyróżnili się istotnie podwyższonym poziomem kompetencji w zakresie ekspozycji społecznej, a ich wyniki w zakresie tej zmiennej były zbliżone do wyników uczniów szkół ogólnokształcących, warto podkreślić, iż istnieją dowody, że kształcenie muzyczne wzmacnia odporność emocjonalną i dobre radzenie sobie w sytuacjach generujących silne pobudzenie emocjonalne (Poraj, 2012; Xie, Cui, 2016), a tym samym przyczynia się do lepszego funkcjonowania w sytuacjach ekspozycji społecznej (por. Kenny, 2011).

W zakresie związku między cechami temperamentu a kompetencjami społecznymi zauważalne są u badanych uczniów, bez względu na typ kształcenia, pewne stałe tendencje. Cechy te współwystępują bowiem w zakresie zróżnicowanych aktywności i doświadczeń ludzkich (por. Miers i in., 2013). Badani uczniowie ujawnili, że im wyższy posiadają poziom aktywności oraz im niższy poziom reaktywności emocjonalnej, tym wyższe są ich kompetencje społeczne. U wszystkich badanych grup uczniów stwierdzono dodatnią korelację między wytrzymałością a kompetencjami społecznymi w zakresie ekspozycji publicznej. Ponadto w grupie uczniów szkół muzycznych można zauważyć, że im wyższy przejawiaja poziom kompetencji społecznych w zakresie ekspozycji publicznej i asertywności, tym wyższym charakteryzują się poziomem żwawości i niższym poziomem perseweratywności. Warto podkreślić, że perseweratywność koreluje z kompetencjami społecznymi jedynie w grupie uczniów szkół muzycznych, co może potwierdzać fakt, iż jest to cecha temperamentu wyróżniająca muzyków z uwagi na silną potrzebę udoskonalania efektów własnej pracy i częstego powracania do powtarzania danego zachowania/ćwiczenia prowadzącego do doskonałości wykonawczej (por. Kemp, 1996; Kobori i in., 2011).

Zrealizowane badania wpisały się w nurt badań z zakresu psychologii muzyki i sztuki, dostarczając w pewnym wymiarze nowej wiedzy o specyfice funkcjonowania uczniów polskich szkół artystycznych w porównaniu z funkcjonowaniem uczniów szkół ogólnokształcących, którzy nie rozwijają swojego muzycznego lub plastycznego potencjału. Można pokusić się o stwierdzenie, iż w wybranych aspektach temperamentu i kompetencji społecznych uczniowie szkół muzycznych i ogólnokształcących są do siebie bardziej podobni niż uczniowie szkół muzycznych i plastycznych. Temperament 
i kompetencje społeczne stanowią integralny element funkcjonowania człowieka na każdym etapie rozwoju i w każdej dziedzinie życia. W kontekście rozwoju artystycznego psychospołeczne wymiary funkcjonowania mają ogromne znaczenie dla osiagnięć artystycznych i adaptacji do wymagań profesjonalnego szkolnictwa (Manturzewska, 2014; Nogaj, Owczarz, 2015; Sękowski, 1989; Rados i in., 2003). Wiedza o specyfice funkcjonowania uczniów o zróżnicowanym poziomie uzdolnień artystycznych stanowi uzupełnienie kompetencji pedagogicznych nauczycieli wspomagających rozwój talentów muzycznych i plastycznych. Jednakże brak wyrazistych różnic między uczniami szkół artystycznych a ogólnokształcących pokazuje, iż zdolności artystyczne nie zawsze silnie różnicują wymiary psychospołecznego funkcjonowania osób uzdolnionych. Młodzi artyści stanowią grupę wyjątkową, ale nie jednorodną w swoim psychospołecznym funkcjonowaniu (por. Chruszczewski, 2009). W kontekście implikacji praktycznych wynikających z niniejszych badań warto się zastanowić nad możliwościami wsparcia uczniów szkół plastycznych w zakresie kompetencji związanych z ekspozycją społeczną. Skoro różnice występujące między poszczególnymi grupami uczniów nie są silne, można założyć, że rozwój w poszczególnych obszarach funkcjonowania społecznego jest nie wynikiem specyficznych zdolności artystycznych, ale efektem indywidualnego różnicowania.

Jednym z minusów zrealizowanych badań był brak kontrolowania osiagnięć edukacyjnych uczniów szkół ogólnokształcących i osiągnięć artystycznych i nieartystycznych wśród uczniów szkół muzycznych i plastycznych. Często o specyfice funkcjonowania uzdolnionych artystycznie osób decyduje ich poziom osiagnięć (por. Gembris, Davidson, 2002; North, Hargreaves, 2008; Tarrant, North, Hargreaves, 2009). Niniejsze badania generują szereg kolejnych pytań związanych z innymi psychospołecznymi wymiarami funkcjonowania uczniów szkół artystycznych. W celu uzupełnienia obrazu ich psychologicznych sylwetek warto w przyszłości się skoncentrować na poznaniu sylwetek uczniów szkół baletowych, którzy ujawniają także bardzo specyficzny/indywidualny typ kształcenia artystycznego, a literatura w tym zakresie jest jeszcze mniej powszechna (por. Konaszkiewicz, 1987; 2006; Neumärker i in., 1998; Noremberg, 2013) niż literatura z zakresu psychologii muzyki i sztuki plastycznej.

\section{BIBLIOGRAFIA}

Amos S.P. (1978), Personality Differences Between Established and Less-established Male and Female CreativeArtists. Journal of PersonalityAssessment, 42, 374-377.

Argyle M. (1998), Zdolności społeczne. W: S. Moscovici (red.), Psychologia społeczna w relacji ja-inni, thum. M. Cielecki, 77-104. Warszawa: Wydawnictwa Szkolne i Pedagogiczne.

Bardziejewska M. (2005), Okres dorastania. Jak rozpoznać potencjał nastolatków? W: A.I. Brzezińska (red.), Psychologiczne portrety czlowieka. Praktyczna psychologia rozwojowa, 345-377. Gdańsk: Gdańskie Wydawnictwo Psychologiczne.

Buttsworth L.M., Smith G.A. (1995), Personality of Australian Performing Musicians by Gender and by Instrument. Personality and Individual Differences, 18, 5, 595-603.

Carson D.K., Wagner B.S., Schultz N.W. (2001), Temperament and Gender: Correlates of Toddler Social Competences. Journal of Genetic Psychology, 148, 3, 289-302.

Caspi A., Silva P.A. (1995), Temperamental Qualitie is a Taget Reepredict Personality Traits in Adulthood: Longitudinal Evidence from a Birth Cohort. Child Development, 66, 486-498.

Chruszczewski M. (2004), Profile psychologiczne uczniów średnich szkół muzycznych i plastycznych mających osiagnięcia artystyczne oraz ponadprzeciętnie inteligentnych uczniów szkół średnich. W: S. Popek (red.), Twórczość w teorii i praktyce, 135-143. Lublin: Wydawnictwo UMCS.

Chruszczewski M.H. (2009), Profile uzdolnień. Intelektualne i osobowościowe składniki uzdolnień plastycznych i muzycznych. Warszawa: Wydawnictwo Uniwersytetu Warszawskiego. 
Csikszentmihalyi M. (2005), Przepływ, tłum. M. Wajda-Kacmajor. Warszawa: Wydawnictwo Czarna Owca. Davidson J.W. (2007), Bodily Communication in Musical Performance. W: D. Miell, R. MacDonald, D.J. Hargreaves (eds.), Mucial Communiaction, 215-237. Oxford, New York: Oxford University Press.

Davies J.B. (1978), The Psychology of Music. London: Hutchinson.

Dews C.L.B., Williams M.S. (1989), Students Musicians' Personality Styles, Stresses and Coping Patterns. Psychology of Music, 17, 37-47.

Ericsson K.A. (1996), The Road to Excellence: The Acquisition of Expert Performance in the Arts and Science, Sports and Games. New York: Lawrence Erlbaum.

Ericsson K.A. (2006), The Influence of Experience and Deliberate Practice on the Development of Superior Expert Performance. W: K.A. Ericsson, N. Charness, P.J. Feltovich, R.R. Hoffman (eds.), The Cambridge Handbook of Expertise and Expert Performance, 685-705. Cambridge: Cambridge University Press.

Ericsson K.A., Krampe R.T., Tesch-Römer C. (1993), The Role of Deliberate Practice in the Acquisition of Expert Performance. Psychological Review, 100, 3, 363-406.

Freeman J. (2010), Gifted Lives. What Happens when the Gifted Children Grow Up. London, New York: Routledge.

Furnham A., Crump J. (2013), The Sensitive, Imaginative, Articulate Art Student and Conservative, Cool, Numerate Science Student: Individual differences in Art and Science Students. Learning and Individual Differences, 25, 150-155.

Gaunt H., Hallam S. (2009), Individuality in the Learning of Musical Skills. W: S. Hallam, I. Cross, M. Thaut (eds.), The Oxford Handbook of Music Psychology, 274-284. New York: Oxford University Press.

Gembris H., Davidson J.W. (2002), Environmental Influences. W: R. Parncutt, G.E. McPherson (eds.), Thescience and Psychology of Music Performance, 17-30. New York: Oxford University Press.

Jankowski W. (2002), Polskie szkolnictwo muzyczne. Geneza i ewolucja systemu. Warszawa: Akademia Muzyczna im. Fryderyka Chopina, Centrum Edukacji Artystycznej.

Jaślar-Walicka E. (1999), Różne modele nauczycieli w przebiegu edukacji muzycznej w świetle badań amerykańskich i polskich nad muzykami i talentami muzycznymi. W: M. Manturzewska (red.), Psychologiczne podstawy ksztatcenia muzycznego, 163-170. Warszawa: Akademia Muzyczna im. Fryderyka Chopina.

Juslin P.N. (2007), From Mimesis to Catharsis: Expression, Perception, and Induction of Emotion in Music. W: D. Miell, R. MacDonald, D.J. Hargreaves (eds.), Mucial Communiaction, 85-115. Oxford, New York: Oxford University Press.

Kemp A.E. (1996), The Musical Temperament. Psychology and Personality of Musicians. New York: Oxford University Press.

Kemp A.E. (2009), Individual differences in musical behaviour. W: D.J. Hargreaves, A.C. North (eds.), The Social Psychology of Music, 25-45. New York: Oxford University Press.

Kenny D.T. (2011), The Psychology of Music Performance Anxiety. New York: Oxford University Press.

Kobori O., Yoshie M., Kudo K., Ohtsuki T. (2011), Traits and Cognitions of Perfectionism and Their Relations with Coping Style, Effort, Achievement, and Performance Anxiety in Japanese Musicians. Journal of Anxiety Disorders, 25, 674-679.

Konaszkiewicz Z. (1987), Tancerze polscy - wybrane problemy ksztatcenia i zawodu. Warszawa: Wydawnictwo Akademii Muzycznej im. Fryderyka Chopina.

Konaszkiewicz Z. (red.) (2006), Szkoła baletowa - studia i szkice. Warszawa: Wydawnictwo Akademii Muzycznej im. Fryderyka Chopina.

Kowalski G. (2005), Uczyć sztuki czy kształcić artystów? W: M. Poprzęcka (red.), Polskie szkolnictwo artystyczne. Dzieje - teoria - praktyka, 21-25. Warszawa: Stowarzyszenie Historyków Sztuki.

Langendörfer F. (2008), Personality Differences among Orchestra Instrumental Groups: Just a Stereotype? Personality and Individual Differences, 44, 610-620.

Limont W. (1998), Uzdolnienia plastyczne a inteligencja, zdolności twórcze i style poznawcze. Przeglad Psychologiczny, 41, 1/2, 73-89.

Lupu V. (2013), An Exploration Study of Emotional Intelligence and Emotional Thinking in Students from Fine Arts and Math-IT High Schools. Bulletin Scientific, 1, 35, 36-44. 
Manturzewska M. (1990), Przebieg życia muzyka w świetle badań biograficznych. W: M. Manturzewska, H. Kotarska (red.), Wybrane zagadnienia z psychologii muzyki, 305-327. Warszawa: Wydawnictwa Szkolne i Pedagogiczne.

Manturzewska M. (2014), Psychologiczne wyznaczniki powodzenia w studiach muzycznych. Warszawa: Centrum Edukacji Artystycznej, Uniwersytet Muzyczny Fryderyka Chopina.

Matczak A. (2001), Kwestionariusz Kompetencji Społecznych. Podręcznik. Warszawa: Pracownia Testów Psychologicznych Polskiego Towarzystwa Psychologicznego.

Miers A.C., Blöte A.W., de Rooij M., Bokhorst C.L., Westenberg P.M. (2013), Trajectories of Social Anxiety during Adolescence and Relations with Cognition, Social Competence, and Temperament. Journal of Abnormal Child Psychology, 41, 97-110.

Neumärker K.J., Bettle N., Bettle O., Dudeck U., Neumärker U. (1998), The Eating Attitudes Test: Comparative Analysis of Female and Male Students at the Public Ballet School of Berlin. European Child and Adolescent Psychiatry, 7, 19-23.

Nogaj A.A. (2014), Rola mistrza w rozwoju muzycznej tożsamości młodego adepta sztuki muzycznej. W: G.E. Kwiatkowska, J. Posłuszna (red.), Relacja mistrz-uczeń. Rozważania z perspektywy psychologii muzyki, 82-97. Kraków: Wydawnictwo Aureus.

Nogaj A.A., Ossowski R. (2015), Social Suport as a Mediator for Musical Achievement. Polish Psychological Bulletin, 46, 2, 300-308.

Nogaj A.A., Owczarz U. (2015), Sytuacje trudne a różnice w umiejscowieniu poczucia kontroli uczniów szkół muzycznych i plastycznych. Zeszyty Psychologiczno-Pedagogiczne Centrum Edukacji Artystycznej, 3, 71-78.

Noremberg J. (2013), Uwarunkowania osiagnięć edukacyjnych uczniów szkół baletowych. Zeszyty Psychologiczno-Pedagogiczne CEA, 1, 71-79

North A.C., Hargreaves D.J. (2008), The Social and Applied Psychology of Music. New York: Oxford University Press.

Oleszkowicz A., Senejko A. (2011), Dorastanie. W: J. Trempała (red.), Psychologia rozwoju człowieka, 259286. Warszawa: Wydawnictwo Naukowe PWN.

Per M., Beyoglu A. (2011), Personality Types of Students who Study at the Departments of Numeric, Verbal and Fine Arts in Education Faculties. Procedia Social and Behavioral Science, 12, 242-247.

Popek R. (1987), Poziom rozwoju inteligencji i uzdolnień twórczych młodzieży kształconej plastycznie. W: S. Popek (red.), Z badań nad zdolnościami i uzdolnieniami specjalnymi młodzieży, 57-68. Lublin: Wydawnictwo Uniwersytetu Marii Curie-Skłodowskiej.

Popek S.L. (2010), Psychologia twórczości plastycznej. Kraków: Impuls.

Poraj G. (2012), Stres - motor czy hamulec rozwoju i edukacji muzyków? W: E. Kumik, G. Poraj (red.), Konteksty ksztatcenia muzycznego, t. 2: Prace teoretyczne i badawcze, 261-276. Łódź: Akademia Muzyczna im. G. i K. Bacewiczów.

Poraj-Weder M., Sekścińska K. (2012), Postawy wobec siebie i świata czyli sylwetki psychologiczne studentów Akademii Muzycznej w Łodzi. W: E. Kumik, G. Poraj (red.), Konteksty kształcenia muzycznego, t. 2: Prace teoretyczne i badawcze, 277-290. Łódź: Akademia Muzyczna im. G. i K. Bacewiczów.

Rados K., Kovacevic P., Bogunovic B., Ignjatovic T., Acic G. (2003), Psychological Foundations of Success in Learning Music at Elementary School Age. Proceedings of the 5th Triennal ESCOM Conference, 8-13 September 2003, 416-419. Hanover Univeristy of Music and Drama, Germany.

Rispoli K.M., McGoey K.E., Koziol N.A., Schreiber J.B. (2013), The Relations of Parenting, Child Temperament, and Attachment Security in Early Childhood to Social Competence at School Entry. Journal of School Psychology, 51, 643-658.

Rothbart M.K. (2011), Becoming Who We Are: Temperament and Personality in Development. New York: Guilford Press.

Sękowski A. (1989), Osobowość a osiagnięcia artystyczne uczniów szkół muzycznych. Wrocław, Warszawa, Kraków, Gdańsk, Łódź: Zakład Narodowy im. Ossolińskich, Wydawnictwo Polskiej Akademii Nauk.

Smith A.M., Maragos A., Van Dyke A. (2000), Psychology of the Musician. W: R. Tubiana, P.C. Amadio (eds.), Medical Problems of the Instrumentalist Musician, 135-170. London: Martin Dunitz Ltd.

Sloboda J.A., Howe M.J.A. (1999), Musical Talent and Individual Differences in Musical Achievement. Psychology of Music, 27, 52, 52-54. 
Sosniak L.A. (1990), The Tortoise, the Hare, and the Development of Talent. W: M.J.A. Howe (ed.), Encouraging the Development of Exceptional Skills and Talents, 109-130. Leicester: The British Psychological Society.

Stoeber J., Eismann U. (2007), Perfectionism in Young Musicians: Relations with Motivation, Effort, Achievement, and Distress. Personality and Individual Differences, 43, 2182-2192.

Strelau J. (2001), Psychologia temperamentu. Warszawa: Wydawnictwo Naukowe PWN.

Strelau J. (2006), Temperament jako regulator zachowania, z perspektywy pótwiecza badań. Gdańsk: Gdańskie Wydawnictwo Psychologiczne.

Strelau J. (2014), Różnice indywidualne. Historia - determinanty-zastosowania. Warszawa: Wydawnictwo Naukowe Scholar, Szkoła Wyższa Psychologii Społecznej.

Tarrant M., North A.C., Hargreaves D.J. (2002), Youth Identity and Music. W: R.A.R. MacDonald, D.J. Hargreaves, D. Miell (eds.), Musical Identities, 134-150. New York: Oxford University Press.

Vaughan Van Hecke A., Mundy P.C., Acra C.F., Block J.J., Delgado Ch.E.F., Parlade M.V., Neal A.R., Meyer J.A., Pomare Y.B. (2007), Infant Joint Attention, Temperament, and Social Competence in Preschool Children. Child Development, 78, 1, 53-69.

Welch G., Ockelford A. (2009), The Role of the Institution and Teachers in Supporting Learning. W: S. Hallam, I. Cross., M. Thaut (eds.), The Oxford Handbook of Music Psychology, 307-319. New York: Oxford University Press.

Whitesel L.S. (1984), Comparing the Personality Characteristics of Male and Female Art. Students with Those of Students in English and Psychology. Studies in ArtEducation, 26, 1, 51-55.

Winner E. (1996), Gifted Children: Myths and Realities. New York: Basic Books.

Wubbenhorst T.M. (1994), Personality Characteristics of Music Educators and Performers. Psychology of Music, 22, 63-74.

Xie G., Cui X. (2016), Effects of Emotional Intelligence and Self-Leadership on Students' Coping with Stress. Social Behaviour and Personality, 44, 5, 853-864.

Zawadzki B., Strelau J. (1997), Formalna Charakterystyka Zachowania - Kwestionariusz Temperamentu. Podręcznik. Warszawa: Pracownia Testów Psychologicznych Polskiego Towarzystwa Psychologicznego. 